\title{
High-flow nasal cannula can't be considered non-inferior to noninvasive ventilation in patients with chronic obstructive pulmonary disease who develop respiratory failure after extubation
}

\author{
Robert V. Curtis, Badih A. Kabchi and Shehabaldin Alqalyoobi*
}

We read the article published recently in Critical Care by Tan et al. with great interest. We appreciate their effort to evaluate high flow nasal cannula (HFNC) usage in post-extubated chronic obstructive pulmonary disease (COPD) patients with respiratory failure [1]. A noninferiority study is a reasonable approach given NIV has shown benefit in post-extubation studies [2-4]. Unlike superiority trials, non-inferiority studies establish noninferiority by rejecting a null hypothesis that the tested treatment is worse than the comparator by a pre-established minimum difference (non-inferiority cutoff or delta) based on results from prior studies [5]. However, several issues in this study prevent us from reaching this conclusion.

First, Tan et al. anticipated an NIV failure rate of $22 \%$ based on prior trials. The authors determined a delta of 9\% for non-inferiority cutoff. They found that the experimental group (HFNC) had failure rates less than the control group (NIV), $22.7 \%$ vs. $28.6 \%$, respectively. The absolute risk difference was $-5.8 \%$ (CI $95 \%$; -23.8 to

This comment refers to the article available online at https://doi.org/10.1186/ s13054-020-03214-9.

*Correspondence: alqalyoobis19@ecu.edu

Present Address: Division of Pulmonary, Critical Care and Sleep Medicine, Department of Internal Medicine, East Carolina University-Brody School

of Medicine, Mail Stop 628, 3E-149, Greenville, NC 27834, USA
12.5). Since the CI range extends beyond the predetermined non-inferiority cut-off, inferiority is still a possibility and the study should be considered inconclusive [5]. For further clarification, we created a forest plot to visualize the primary outcomes CIs in relation to the delta point (Fig. 1).

Second, the suggested sample size of 44 subjects per group seems insufficient. We don't have a description of the calculations used by Tan et al., but using their assumptions we calculated that at least 216 patients per arm would be required to prove non-inferiority with a difference of less than $9 \%$, an alpha of 0.05 , and a beta of 0.2 (it is worth noting that in the paper it is stated an alpha of 0.5 instead of 0.05 , which we think is a typo since such a large error margin is not considered acceptable). A trial with a similar design referenced by Tan et al. [4] calculated a sample size of 300 patients per arm using similar assumptions.

Third, the failure rate in the NIV arm is higher than expected $(28.6 \%$ vs $22 \%$, OR $=1.3)$, and is higher than other previous studies [2-4]. This may create bias in favor of non-inferiority and should have been discussed further in the paper.

In summary, we conclude that the results of Tan et al's study can't prove non-inferiority of HFNC compared to NIV, although it doesn't exclude it either. Besides, further clarification regarding the sample size is required. original author(s) and the source, provide a link to the Creative Commons licence, and indicate if changes were made. The images or other third party material in this article are included in the article's Creative Commons licence, unless indicated otherwise in a credit line to the material. If material is not included in the article's Creative Commons licence and your intended use is not permitted by statutory regulation or exceeds the permitted use, you will need to obtain permission directly from the copyright holder. To view a copy of this licence, visit http://creativecommons.org/licenses/by/4.0/. The Creative Commons Public Domain Dedication waiver (http://creativeco mmons.org/publicdomain/zero/1.0/) applies to the data made available in this article, unless otherwise stated in a credit line to the data. 


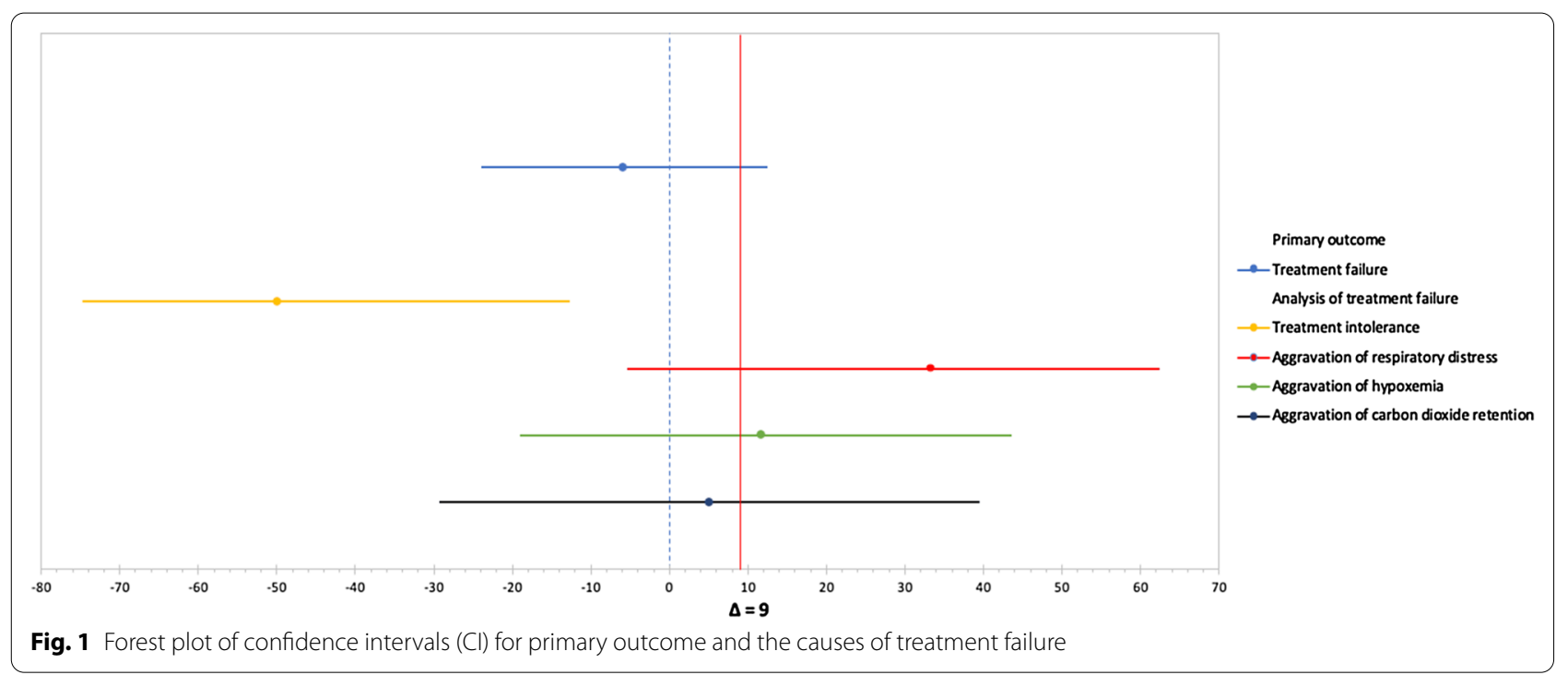

Authors' response

Jiayan Sun, Dingyu Tan, Joseph Harold, Walline Jun Xu

Dear Editor,

We would like to thank Drs. Curtis, Kabchi and Alqalyoobi for their detailed comments and helpful feedback. We should first emphasize that the primary endpoint in our study was a composite of re-intubation and switching between non-invasive ventilation (NIV) and high-flow nasal cannula (HFNC), which would better reflect a real-life treatment failure of HFNC or NIV [6]. This composite endpoint had a significant impact on setting the estimated NIV failure rate and sample size. Most previous studies have defined a NIV failure as only tracheal intubation. In our study, the NIV failure rate was $28.6 \%$, but, again, this was a composite of the re-intubation and treatment switch rates, leading to a higher overall NIV failure rate in our study.

In the study with a sample size of 300 mentioned in the letter, the baseline re-intubation rate for the two groups was set at the same value, though the non-inferiority cutoff value was similar to our study [4]. However, recent studies have shown that the treatment failure rate of HFNC is $4-12 \%$ lower than that of NIV $[4,7,8]$, which significantly reduced the sample size required for our study. With reference to the trial of Kullberg et al. [9], according to different baseline failure rates (maximum 12\% difference), we calculated that at least 88 patients would be required to assess a noninferiority cutoff at $9 \%$ using an $\alpha=0.05$ (0.50 alpha was indeed a typo) and a $\beta=0.20$.
Combining the statistical trend of high probability, we were careful in our paper to conclude that HFNC after extubation did not result in increased rates of treatment failure compared with NIV, though the CI range extends beyond the predetermined non-inferiority cut-off. Nevertheless, we believe the data we presented is a helpful first step to comparing HFNC with NIV in chronic obstructive pulmonary disease (COPD) patients.As the first randomized controlled trial to compare the failure rate of HFNC to NIV in patients with COPD after invasive ventilation, there may be different interpretations of the ideal sample size and test values. We set the feasible minimum sample size according to our calculations and found that the absolute risk difference between HFNC and NIV was $-5.8 \%$ (CI 95\%; -23.8 to 12.5 ). We agree that future studies with larger sample sizes should be able to narrow the CI range and help determine the best use of HFNC.

\section{Acknowledgements}

None

Authors' contributions

RVC, BAK, and SA contributed to interpretation of results. RVC, BAK, and SA contributed to manuscript preparation. All authors read and approved the final manuscript.

\section{Funding}

None. 
Availability of data and materials

Not applicable.

Ethics approval and consent to participate

Not applicable.

\section{Consent for publication}

Not applicable.

\section{Competing interests}

The authors declare that they have no competing interests.

Published online: 23 November 2020

\section{References}

1. Tan D, Walline JH, Ling B, Xu Y, Sun J, Wang B, Shan X, Wang Y, Cao P, Zhu $Q$, et al. High-flow nasal cannula oxygen therapy versus non-invasive ventilation for chronic obstructive pulmonary disease patients after extubation: a multicenter, randomized controlled trial. Crit Care. 2020;24(1):489.

2. Burns KE, Adhikari NK, Keenan SP, Meade MO. Noninvasive positive pressure ventilation as a weaning strategy for intubated adults with respiratory failure. Cochrane Database Syst Rev. 2010;2010(8):CD004127.

3. Esteban A, Frutos-Vivar F, Ferguson ND, Arabi Y, Apezteguia C, Gonzalez M, Epstein SK, Hill NS, Nava S, Soares MA, et al. Noninvasive positivepressure ventilation for respiratory failure after extubation. N Engl J Med. 2004;350(24):2452-60

4. Hernandez G, Vaquero C, Colinas L, Cuena R, Gonzalez P, Canabal A, Sanchez S, Rodriguez ML, Villasclaras A, Fernandez R. Effect of postextubation high-flow nasal cannula vs noninvasive ventilation on reintubation and postextubation respiratory failure in high-risk patients: a randomized clinical trial. JAMA. 2016;316(15):1565-74.

5. Mauri L, D'Agostino RB Sr. Challenges in the design and interpretation of noninferiority trials. N Engl J Med. 2017;377(14):1357-67.

6. Stéphan F, Barrucand B, Petit P, Rézaiguia-Delclaux S, Médard A, Delannoy B, Cosserant B, Flicoteaux G, Imbert A, Pilorge C, et al. High-flow nasal oxygen vs noninvasive positive airway pressure in hypoxemic patients after cardiothoracic surgery: a randomized clinical trial. JAMA. 2015;313(23):2331-9.

7. Frat JP, Thille AW, Mercat A, Girault C, Ragot S, Perbet S, Prat G, Boulain T, Morawiec E, Cottereau A, et al. High-flow oxygen through nasal cannula in acute hypoxemic respiratory failure. N Engl J Med. 2015;372(23):2185-96.

8. Doshi P, Whittle JS, Bublewicz M, Kearney J, Ashe T, Graham R, Salazar S, Ellis TW Jr, Maynard D, Dennis R, et al. High-velocity nasal insufflation in the treatment of respiratory failure: a randomized clinical trial. Ann Emerg Med. 2018;72(1):73-83.e5.

9. Kullberg BJ, Sobel JD, Ruhnke M, Pappas PG, Viscoli C, Rex JH, Cleary $J D$, Rubinstein E, Church LWP, Brown JM, et al. Voriconazole versus a regimen of amphotericin $B$ followed by fluconazole for candidaemia in non-neutropenic patients: a randomised non-inferiority trial. Lancet. 2005;366(9495):1435-42.

\section{Publisher's Note}

Springer Nature remains neutral with regard to jurisdictional claims in published maps and institutional affiliations.
Ready to submit your research? Choose BMC and benefit from:

- fast, convenient online submission

- thorough peer review by experienced researchers in your field

- rapid publication on acceptance

- support for research data, including large and complex data types

- gold Open Access which fosters wider collaboration and increased citations

- maximum visibility for your research: over $100 \mathrm{M}$ website views per year

At BMC, research is always in progress.

Learn more biomedcentral.com/submissions 